Check for updates

Cite this: RSC Adv., 2018, 8, 9587

\title{
An efficient and scalable synthesis of potent TLR2 agonistic $\mathrm{PAM}_{2} \mathrm{CSK}_{4} \dagger$
}

\author{
Arshpreet Kaur, ${ }^{a}$ Poonam, ${ }^{a}$ Madhuri T. Patil, ${ }^{b}$ Surinder K. Mehta (D) ${ }^{a}$ \\ and Deepak B. Salunke (D)*a
}

\begin{abstract}
Diacylated $\mathrm{PAM}_{2} \mathrm{CSK}_{4}$, a highly expensive lipopeptide with desirable aqueous solubility and a broad spectrum of cytokine/chemokine induction is a most potent dual (human and murine) Toll-Like Receptor-2 (TLR2) agonist. Besides such thrilling characteristics, its synthetic process is not reported in the literature. The present report describes an efficient and scalable 20 step synthesis of $\mathrm{PAM}_{2} \mathrm{CSK}_{4}$ in good yield (all steps $>60 \%$ ) along with a clear description of the hindrances and easy solutions adopted in each step. Overall, a convergent synthetic approach was adopted involving synthesis of appropriately protected starting materials, synthesis of a key backbone skeleton $\mathrm{PAM}_{2} \mathrm{CS}$, synthesis of a tetralysine fragment and the final coupling to yield $\mathrm{PAM}_{2} \mathrm{CSK}_{4}$. Tedious column chromatography was avoided on a large scale in many steps.
\end{abstract}

Received 13th February 2018

Accepted 26th February 2018

DOI: 10.1039/c8ra01387j

rsc.li/rsc-advances

a major concern for immunologists. Natural ligands for all the TLRs have been identified except for TLR10. These ligands include lipopeptides (recognized by TLR2 in combination with TLR1 or TLR6), lipopolysaccharides (LPS) (TLR4), microbial protein components such as flagellin (TLR5), nucleic acids, for example, single-stranded RNA (TLR7 and TLR8) or doublestranded RNA (TLR3) and CpG DNA (TLR9). ${ }^{5}$

Among all the human TLRs, TLR2 is known to sense remarkable array of bacterial, fungal, and viral products as well as inflammatory self-segments. ${ }^{6}$ TLR2 is receptor equipped for experiencing heterodimerization with TLR1 (for triacylated lipopeptides) and TLR6 (for diacylated lipopeptides). ${ }^{7}$ Additionally, TLR2 has been widely explored as a promising target for drug discovery (Table 1). SPM-105, a TLR2 agonistic autoclaved mycobacteria was considered in preclinical examinations for the treatment of cancer ${ }^{8}$ and OM-174, a lipid A derivative with double activity on TLR2 and TLR4, was tried as a chemotherapeutic agent for viability against unmanageable strong tumors. ${ }^{9}$ Likewise, bacterial porins showing TLR2 agonistic activity have been utilized in vaccines. Specifically, OmpS1 and OmpS2, the external film proteins from Salmonella typhi, are known to actuate TLR2 and TLR4 and are used for immunization in typhoid fever. ${ }^{10}$ Among the several TLR2 agonistic biomacromolecules, the lipopeptides derived from cell-wall components are the most intense ligands. ${ }^{6} \mathrm{PAM}_{3} \mathrm{CSK}_{4}(N$-palmitoyl-S-[2,3-bis(palmitoyloxy)-(2RS)-propyl]- $R$-cysteinyl- $S$-seryl$S$-lysyl-S-lysyl-S-lysyl-S-lysine) as well as $\mathrm{PAM}_{2} \mathrm{CSK}_{4}(S$-[2,3-bis(palmitoyloxy)-(2RS)-propyl]-R-cysteinyl- $S$-seryl-S-lysyl-S-lysyl$S$-lysyl-S-lysine) are the greatly explored synthetic lipopeptides used against parasitic infections such as leishmania, ${ }^{11}$ malaria, ${ }^{12}$ influenza ${ }^{13}$ and also worked well in suppression of asthma manifestations ${ }^{14}$ and melanoma ${ }^{15}$ (Table 1).

${ }^{a}$ Department of Chemistry and Centre of Advanced Studies in Chemistry, Panjab University, Chandigarh 160014, India.E-mail: salunke@pu.ac.in

${ }^{b}$ Department of Chemistry, Mehr Chand Mahajan DAV College for Women, Sector 36A, Chandigarh 160036, India

$\dagger$ Electronic supplementary information (ESI) available: Activity profiling table for $\mathrm{PAM}_{2} \mathrm{CSK}_{4}$ with references; ${ }^{1} \mathrm{H}$ NMR, ${ }^{13} \mathrm{C}$ NMR and MS spectra of intermediates and final product $\mathrm{PAM}_{2} \mathrm{CSK}_{4}$. See DOI: $10.1039 / \mathrm{c} 8 \mathrm{ra01387j}$ 
Table 1 TLR2 agonists as vaccine adjuvant and therapeutic agents in drug discovery

\begin{tabular}{llll}
\hline Compound & Target & Indication & Drug class \\
\hline SMP-105 & TLR2 agonist & Bladder cancer $^{2}$ & Autoclaved mycobacteria $^{8}$ \\
OM-174 & TLR2 \& 4 agonist & Cancer chemotherapy & Lipid A derivative $^{9}$ \\
OmpS1 \& OmpS2 (Salmonella typhi) & TLR2 \& 4 agonist & Typhoid fever vaccine & Bacterial porins $^{10}$ \\
PAM $_{3}$ CSK $_{4} / \mathrm{PAM}_{2}$ CSK $_{4}$ & TLR2 agonist & Leishmania infection & Lipoprotein $^{11}$ \\
PAM $_{3}$ CyS $_{\text {PAM }}$ Cys & TLR2 agonist & Malaria LbL vaccine & Lipoprotein conjugate $^{12}$ \\
PAM $_{2}$ CSK $_{4}$ & TLR2 agonist & Influenza vaccine & Lipoprotein $^{13}$ \\
PAM $_{3}$ Cys & TLR2 agonist & Suppression of asthma manifestations & Lipoprotein $^{14}$ \\
PAM $_{3}$ CSK $_{4}$ & TLR2 agonist & Melanoma cancer & Lipoprotein $^{15}$
\end{tabular}

Several palmitoyl lipopeptides are being explored as TLR2 agonists. Out of the analogs $\mathrm{PAM}_{3}$ Cys-Ser-Ser-Asn-Ala, $\mathrm{PAM}_{3}-$ Cys-Ser-(Lys) $)_{4}, \mathrm{PAM}_{3}$ Cys-Ala-Gly, and $\mathrm{PAM}_{3}$ Cys-Ser, $\mathrm{PAM}_{3} \mathrm{CSK}_{4}$ was found to be a potent activator due to the presence of hydrophilic lysine residues that enhanced its solubility. ${ }^{16}$ On the other hand, the diacylated $\mathrm{PAM}_{2} \mathrm{CSK}_{4}$ lipopeptide has better aqueous solubility as compared to triacylated $\mathrm{PAM}_{3} \mathrm{CSK}_{4}$. The vaccines with peptide epitopes and dipalmitoyl lipopeptide constructs are most soluble and effective vaccine candidates. ${ }^{17}$ Moreover, dipalmitoyl lipopeptide is more potent immunostimulant than tripalmitoyl lipopeptide for macrophages and splenocytes. ${ }^{18}$ It is noteworthy to mention that an extensive SAR investigation on $\mathrm{PAM}_{2} \mathrm{CSK}_{4}$ resulted in highly active monoacyl lipopeptides but these molecules being human specific were not further explored in the preclinical investigation. ${ }^{19}$

After the complete review of literature, the diacylated $\mathrm{PAM}_{2} \mathrm{CSK}_{4}$ lipopeptide was found to be the most potent dual (human and murine) TLR2 agonist having desirable aqueous solubility showing broad spectrum of cytokine/chemokine inducing property. ${ }^{20}$ This synthetic lipopeptide is equipotent $\left(\mathrm{EC}_{50}=67 \mathrm{pm}\right)^{21}$ in its NF- $\mathrm{\kappa B}$ inducing activity relative to LPS. $^{22,23}$ Induction of class I cytokine IL-6, class II cytokine IL-10, IFN- $\beta$, IFN- $\gamma$, and activation of TNF receptors is reported by this ligand. $\mathrm{PAM}_{2} \mathrm{CSK}_{4}$ is also known to induce several chemokines namely, MCP-1, CXCL6, GRO, CXCL8, CCL20, CXCL10 and CCL5 (Table S1, page S3 ESI $\dagger$ ). ${ }^{20-26} \mathrm{PAM}_{2} \mathrm{CSK}_{4}$ is not only a potent TLR2 agonist but also possess property to self assemble at critical aggregation concentration ( $\mathrm{cac}=0.035 \mathrm{wt} \%)$. It self assemble into small spherical micelles distinct from worm-like micelles observed in case of $\mathrm{PAM}_{3} \mathrm{CSK}_{4} \cdot{ }^{27}$ The distinct mode of self assembly may be related to its bioactivity and could be a useful parameter for the formulation.

$\mathrm{PAM}_{2} \mathrm{CSK}_{4}$ is highly expensive TLR2 ligand available from Invivogen ${ }^{28}$ but its synthetic process is not yet described in the literature. These observations further drove our interest to optimize the large-scale synthesis of $\mathrm{PAM}_{2} \mathrm{CSK}_{4}$ with minimum possible investment. The present report describes an efficient and scalable first complete synthesis of this TLR2 agonistic $\mathrm{PAM}_{2} \mathrm{CSK}_{4}$.

\section{Results and discussion}

$\mathrm{PAM}_{2} \mathrm{CSK}_{4}$, a synthetic analog of MALP-2 consists of two major components, a lipo-dipeptide $\mathrm{PAM}_{2} \mathrm{CS} \quad 3$ and a tetrapeptide of lysine $\mathrm{K}_{4} 4$ (Fig. 1). The retrosynthetic analysis shows that the constituents necessary for the synthesis are $R$-4-(iodomethyl)-2,2-dimethyl-1,3-dioxalane 5, Boc-Cys$\mathrm{OH} 6$ and $\mathrm{H}-\mathrm{Ser}\left(\mathrm{O}^{t} \mathrm{Bu}\right)-\mathrm{O}^{t} \mathrm{Bu}$ 7. Based on the commercial availability and the cost of these synthons, a convergent synthetic approach involving synthesis of appropriately protected starting materials (Scheme 1), synthesis of key backbone skeleton (Scheme 2), synthesis of tetralysine fragment (Scheme 3) and final coupling to yield $\mathrm{PAM}_{2} \mathrm{CSK}_{4}$ (Scheme 4) was proposed for this synthesis.

The key synthon $R$-4-(iodomethyl)-2,2-dimethyl-1,3dioxalane 5 (Scheme 1) was synthesized from commercially available $S$-2,2-dimethyl-1,3-dioxolane-4-methanol 12 in good yield. The synthesis involved use of iodine (1.3 eq.), triphenylphosphine (1.2 eq.) and imidazole (3 eq.) reagent in toluene at $90{ }^{\circ} \mathrm{C}$ where imidazole acted as general base and an acid scavenger. ${ }^{29}$ The excess amount of iodine was necessary to enhance the formation of an alkoxyphosphonium iodide salt which slowly decomposes by $\mathrm{S}_{\mathrm{N}} 2$ mechanism to form product $5 .^{30} \mathrm{~A}$ tedious column chromatography purification was also required to remove the triphenylphosphine oxide (TPPO).

The procedure was improved by replacing the solvent toluene with THF or DCM, where the reaction proceeded at room temperature and TPPO was removed by complexation using zinc chloride $\left(\mathrm{ZnCl}_{2}\right)$ as described by Batesky and coworkers. ${ }^{31}$ This protocol was applied to avoid column chromatography at large scale by precipitating out triphenylphosphine oxide as $\mathrm{ZnCl}_{2}\left(\mathrm{Ph}_{3} \mathrm{PO}\right)_{x}$ complex.

The high price of $\mathrm{H}-\mathrm{Ser}\left(\mathrm{O}^{t} \mathrm{Bu}\right)-\mathrm{O}^{t} \mathrm{Bu}(5 \mathrm{~g}$, Rs. 13133 from Bachem) 7 required on large scale was another key factor to be considered in this synthesis. Several methods have been reported for the synthesis of tert-butyl ethers and esters but the distinct and easy protocol was the protection of both hydroxyl and carboxylic acid functionalities in one pot. ${ }^{32}$ The adopted procedure involved use of tert-butyl acetate for the protection of hydroxyl and carboxylic acid group of $\mathrm{L}$-serine in the presence of $70 \% \mathrm{HClO}_{4}$ (Scheme 1) to yield pure oily product 7 without any need of column chromatography. ${ }^{33}$

A lipopeptide backbone skeleton 3 mainly responsible for the agonistic activity was synthesized in 8 steps (Scheme 2). L-Cystine was used as a precursor for the synthesis wherein, the initial step involved the protection of $\alpha$-amine group of L-cystine 14 (Scheme 2) using di-tert-butyl dicarbonate $\left(\mathrm{Boc}_{2} \mathrm{O}\right)$ to obtain di-Boc-cystine $15 .{ }^{34}$ After the completion of reaction, 
$10 \% \mathrm{HCl}$ solution ( $15 \mathrm{~mL}$ for $2 \mathrm{~g}$ batch) was directly added to the reaction mixture at $0{ }^{\circ} \mathrm{C}$ and the crude product 15 was precipitated out and washed with chilled distilled water to remove impurities. No column chromatographic purification was required and the crude product $\mathbf{1 5}$ was used as it is for further transformations. The coupling reaction of $(S)$-tertbutyl-2-amino-3-tert-butoxypropanoate 7 and di-Boc-cystine 15 was carried out using 1-ethyl-3-(3-dimethylaminopropyl) carbodiimide (EDCI) and 1-hydroxybenzotriazole (HOBt) in DMF. The column chromatography at this step was also avoided as the addition of crushed ice in the reaction mixture afforded crude product $\mathbf{1 6}$ (85\% yield) which was found to be good enough to be used as it is. The reaction was carried out at up to $10 \mathrm{~g}$ scale and only a small amount was column purified to record the analytical data.

Various reagents are reported in literature for the cleavage of disulfide bond. ${ }^{35}$ Use of $\mathrm{Bu}_{3} \mathrm{P}$ reagent (50\% solution in ethylacetate) was found to be more cost effective while working on large scale. The crucial point for the reaction was the addition of water ( $1 \mathrm{~mL}$ for $1 \mathrm{~g}$ batch). The reaction didn't proceed even after prolong reaction hours if enough quantity of water was not added into the reaction mixture. The solvent was evaporated under reduced pressure and the crude product $\mathbf{1 7}$ was used as it is for next step. The crude product 17 on reaction with synthon 5 in presence of $\mathrm{K}_{2} \mathrm{CO}_{3}$ in DMF solvent afforded compound 18 in excellent yield $(90 \%)$. It is noteworthy to mention that no

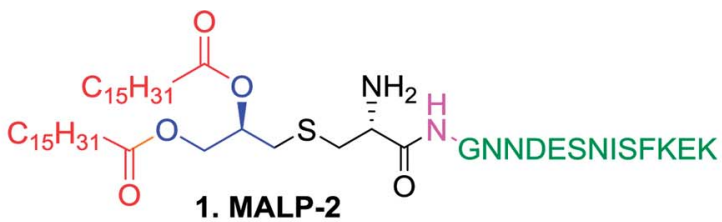<smiles>CCCCCCCCCCCCCCCC(=O)OC[C@H](CSC[C@H](N)C(=O)N[C@@H](CO)C(=O)NCC)OC(=O)CCCCCCCCCCCC</smiles>

2. $\mathrm{PAM}_{2} \mathrm{CSK}_{4}$ (TLR2/6 response)

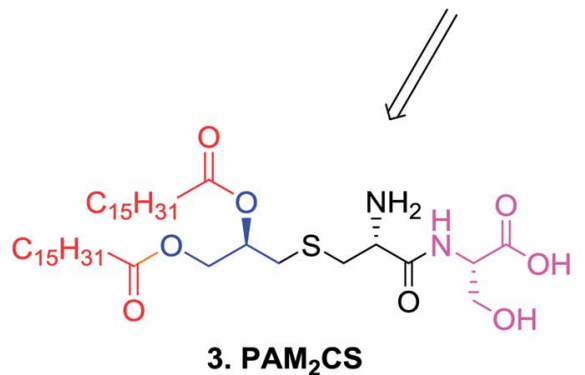

3. $\mathrm{PAM}_{2} \mathrm{CS}$

A lipo-dipeptide backbone skeleton

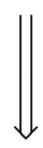<smiles>C=C</smiles><smiles>CCCCCN</smiles><smiles>NCCCCC(NC(=O)[C@@H](N)CCCCN)C(=O)N[C@@H](CCCCN)C(=O)O</smiles>

4. Terapetida $\mathrm{K}_{4}$



Fig. 1 Retrosynthetic approach for $\mathrm{PAM}_{2} \mathrm{CSK}_{4}$. 
<smiles>CC1(C)OCC(CO)O1</smiles><smiles>CCCCOC(=O)C(N)CCCCCCCCCCC(=O)O</smiles>

Scheme 1 Synthesis of reagents. Conditions: (i) $\mathrm{PPh}_{3}, \mathrm{I}_{2}$, imidazole, THF, rt, 12 h. (ii) tert-Butyl acetate, $70 \% \mathrm{HClO}_{4}, 6 \mathrm{~h}$.

column chromatography was required for the purification of product 18 and the addition of crushed ice resulted in the formation of solid product in pure form.

Compound 18 was further treated with $70 \%$ acetic acid and stirred at room temperature for $16 \mathrm{~h}$ to furnish compound 19 in quantitative yield (96\%). ${ }^{36}$ Compound 19 on $O$-palmitoylation using palmitoyl chloride and $\mathrm{Et}_{3} \mathrm{~N}$ in the presence of catalytic amount of 4-dimethylaminopyridine (DMAP) afforded compound 20 which was purified by column chromatography. ${ }^{21}$ The global deprotection of Boc and tert-butyl ether functionalities was done by stirring the solution of compound 20 in TFA for 30 minutes at $25^{\circ} \mathrm{C}$. Evaporation of TFA in order to get pure product 21 was crucial and it was achieved by co-evaporation of the crude product with chloroform and dichloromethane till a white solid product was obtained which was confirmed by mass spectrometry. The solid TFA salt of amine was further treated with excess of di-tert-butyl dicarbonate and $\mathrm{Et}_{3} \mathrm{~N}$ to furnish compound $\mathbf{2 2}$ ready for final coupling with tetralysine residue. ${ }^{37}$

The terapeptide $\mathrm{H}-[\mathrm{Lys}(\mathrm{Boc})]_{4}-\mathrm{O}^{t} \mathrm{Bu} \mathbf{3 1}$ was synthesized in eight steps (Scheme 3) starting from commercially available carboxylic acid precursor Fmoc-Lys(Boc)-OH 23. The amine precursor of the appropriately protected lysine was synthesized in two steps as described by Pratesi $e t a .^{38}$ The general method for protection of carboxylic acid as tert-butyl esters involved the use of coupling reagents (EDCI and HOBt). In the present approach, a mixed anhydride was prepared using di-tert-butyl dicarbonate which on reaction with tert-butanol resulted in the formation of product $24 .^{38}$ This protocol was found to be clean and high yielding. Further, compound 25 was obtained by treating the DMF solution of Fmoc-[Lys(Boc)]-O ${ }^{t} \mathrm{Bu} 24$ with $20 \%$ piperidine. The synthesis of $\mathrm{H}-[\operatorname{Lys}(\mathrm{Boc})]_{2}-\mathrm{O}^{t} \mathrm{Bu} 27$ was obtained by the coupling reaction of reagent 23 and $\mathrm{H}-[\mathrm{Lys}(\mathrm{Boc})]-\mathrm{O}^{t} \mathrm{Bu} 25$ followed by the deprotection of Fmoc group as described. The formation of product 27 was confirmed by ESI-MS and ${ }^{1} \mathrm{H}$ NMR. ${ }^{39}$

The formation of tripeptide $\mathrm{H}-[\mathrm{Lys}(\mathrm{Boc})]_{3}-\mathrm{O}^{t} \mathrm{Bu} 29$ was achieved as mentioned above by using coupling reagents in DMF and following deprotection of Fmoc group. These reactions were reproducible and scalable in grams $(2 \mathrm{~g})$ with $74 \%$ and $86 \%$ yields, respectively. Similarly, the tetrapeptide $\mathrm{H}$ $[\mathrm{Lys}(\mathrm{Boc})]_{4}-\mathrm{O}^{t} \mathrm{Bu} 31$ was synthesized through the coupling of starting precursor 23 with intermediate 29 and subsequent treatment with $20 \%$ piperidine with acceptable yields. The formation of tetrapeptide $\mathrm{H}-[\mathrm{Lys}(\mathrm{Boc})]_{4}-\mathrm{O}^{t} \mathrm{Bu} \mathbf{3 1}$ was confirmed through mass spectrometric analysis. Ionic liquid mediated Fmoc removal ${ }^{40}$ as well as use of polymer-bound piperazine ${ }^{19}$ were the probable alternatives to avoid the column chromatography to remove the side products during this deprotection step but the column chromatography was found to be cost effective as well as simple during this process optimization.

The penultimate coupling of compound 22 with $\mathrm{H}$ [Lys(Boc) $]_{4}-\mathrm{O}^{t} \mathrm{Bu} 31$ (Scheme 4) using EDCI and HOBt coupling reagents in DMF resulted in the formation of an adduct 32 which on treatment with $\mathrm{HCl}$ in dioxane yielded the desired $\mathrm{PAM}_{2} \mathrm{CSK}_{4} 2$ in quantitative yield.



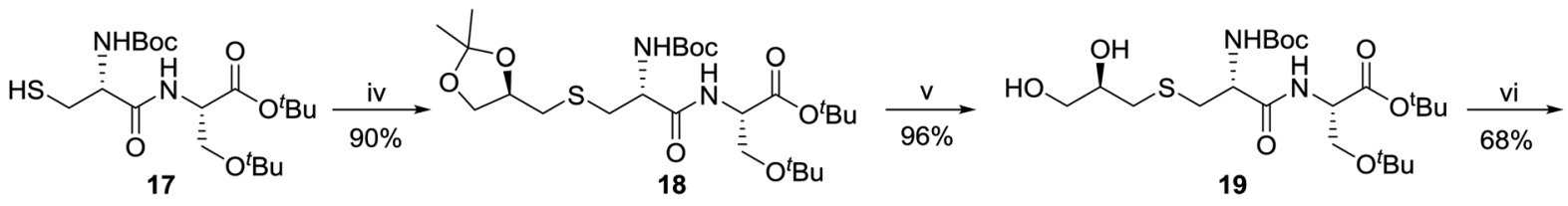

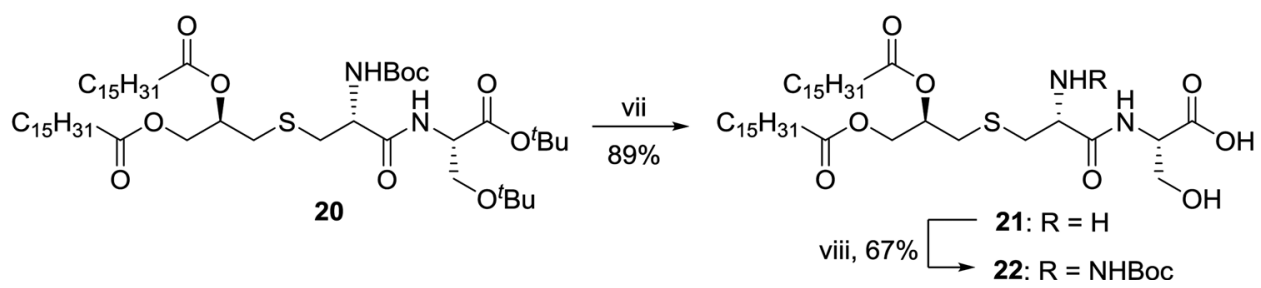

Scheme 2 Synthesis of $\mathrm{PAM}_{2} \mathrm{CS}$. Conditions: (i) $\mathrm{Boc}_{2} \mathrm{O}, \mathrm{Et}_{3} \mathrm{~N}, \mathrm{H}_{2} \mathrm{O}, \mathrm{rt}, 12 \mathrm{~h}$. (ii) $\mathrm{H}-\mathrm{Ser}\left(\mathrm{O}^{t} \mathrm{Bu}\right) \mathrm{O}^{t} \mathrm{Bu} \cdot \mathrm{HCl}(7), \mathrm{EDCl}, \mathrm{HOBt}, \mathrm{Et}{ }_{3} \mathrm{~N}, \mathrm{DMF}, \mathrm{rt}, 5 \mathrm{~h}$. (iii) Bu $3 \mathrm{P}$,

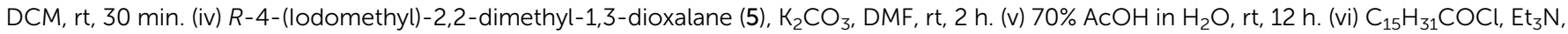
DMAP, DCM, rt, 12 h. (vii) TFA, rt, 30 min. (viii) $\mathrm{Boc}_{2} \mathrm{O}, \mathrm{Et}_{3} \mathrm{~N}, \mathrm{DCM}, 4 \mathrm{~h}$. 


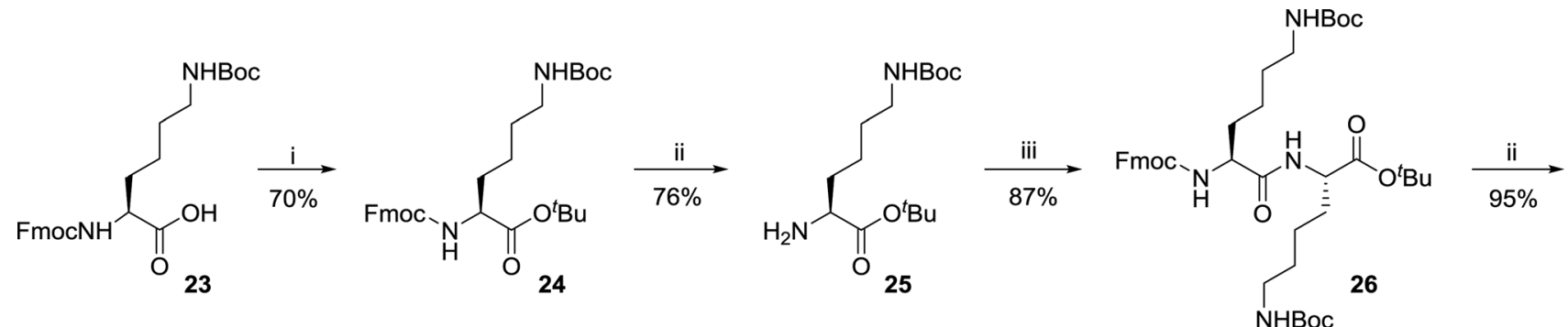

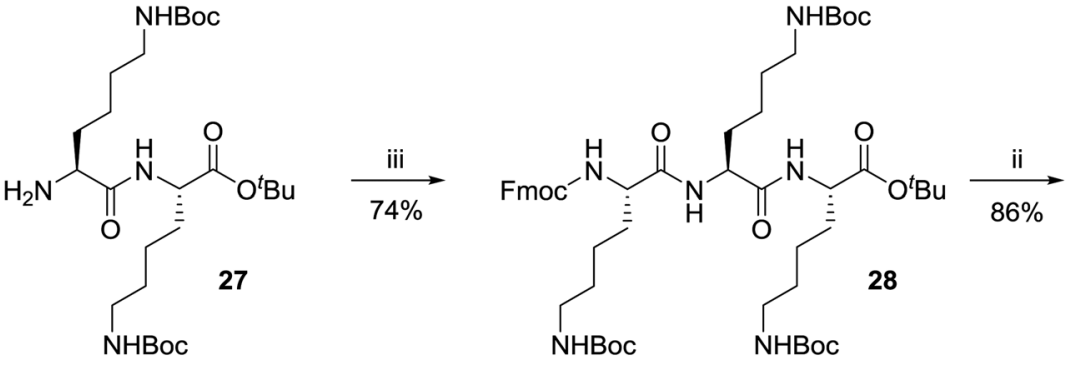

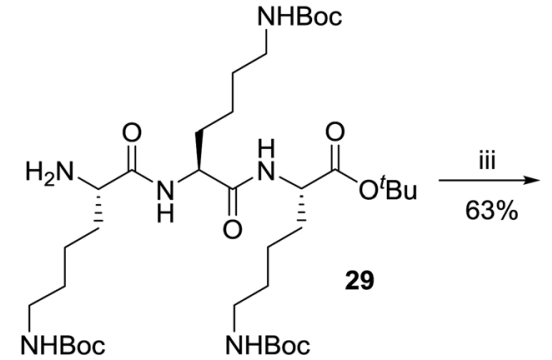<smiles>CCCCNC(=O)OCc1ccccc1</smiles><smiles>CCCCOC(=O)NCCCC[C@H](NC(=O)[C@H](CCCCNC(=O)OC(C)(C)C)NC(=O)[C@H](CCCCNC(=O)OC(C)(C)C)NC(=O)[C@H](N)CCCNC(=O)OCc1ccccc1)C(=O)OC(C)(C)C</smiles>

Scheme 3 Synthesis of tertapeptide $\mathrm{K}_{4}$. Conditions: (i) Di-tert-butyl dicarbonate, DMAP, tert-butyl alcohol, rt, overnight. (ii) 20\% piperidine, DMF, rt, 1 h. (iii) Fmoc-L-Lys(Boc)-OH (23), EDCl, HOBt, Et ${ }_{3} \mathrm{~N}, \mathrm{DMF}, \mathrm{rt}, 6 \mathrm{~h}$.



Scheme 4 Synthesis of $\mathrm{PAM}_{2} \mathrm{CSK}_{4}$. Conditions: (i) $\mathrm{H}-[\mathrm{Lys}(\mathrm{Boc})]_{4}-\mathrm{O}^{t} \mathrm{Bu}$, $\mathrm{EDCl}, \mathrm{HOBt}, \mathrm{Et}_{3} \mathrm{~N}, \mathrm{DMF}, 6 \mathrm{~h}$. (ii) $\mathrm{HCl}$, dioxane, $2 \mathrm{~h}$.

\section{Conclusions}

Overall, with a systematic reaction optimization and appropriate synthetic planning we have demonstrated a twenty step first complete synthesis of $\mathrm{PAM}_{2} \mathrm{CSK}_{4}$ which is scalable and will give an easy access to pharmacologically important TLR2 agonist capable of eliciting immune responses in both human and mice models. The complete procedure involved synthesis of two moieties, $\mathrm{PAM}_{2} \mathrm{CS} 3$ (10 steps) and $\mathrm{K}_{4}$ tetrapeptide 4 (8 steps) and the final coupling and global deprotection to furnish $\mathrm{PAM}_{2} \mathrm{CSK}_{4}$ with $0.55 \%$ overall yield. For the cost effectiveness, the appropriately protected amino acids were synthesized by one step procedure from cheaply available cystine and serine. The present synthetic route will provide an easy access of $\mathrm{PAM}_{2} \mathrm{CSK}_{4}$ to explore its usefulness in the preparation of novel adjuvantic formulations.

\section{Experimental section}

\section{General}

All the reactions were performed with commercially available reagents. The organic solvents were dried by standard procedures wherever necessary. The bulk solvents (hexane, DCM) were distilled before use. All reactions were monitored by thinlayer chromatography (TLC) carried out on Merck silica gel $\mathrm{F}_{254}$ aluminium sheets and visualized with different stains such as phosphomolybdic acid and ninhydrin solutions. All starting amino acid precursors were $\mathrm{L}$ enantiomers and purchased from Sigma aldrich. ${ }^{1} \mathrm{H}$ NMR was recorded on Bruker Advance II 400 or $500 \mathrm{MHz}$ or Jeol FT NMR $300 \mathrm{MHz}$. Mass analysis was performed with Waters, Q-TOF-Micromass (ESI-MS) Spectrometer. 
(R)-4-(Iodomethyl)-2,2-dimethyl-1,3-dioxolane (5)

To a solution of $S$-2,2-dimethyl-1,3-dioxolane-4-methanol 12 $(1.0 \mathrm{~g}, 7.6 \mathrm{mmol})$ in DCM $(10 \mathrm{~mL})$ was added triphenylphosphine $(2.4 \mathrm{~g}, 9.1 \mathrm{mmol})$, imidazole $(1.5 \mathrm{~g}, 22.7 \mathrm{mmol})$, and iodine $(2.5 \mathrm{~g}$, $9.8 \mathrm{mmol}$ ). The reaction mixture was stirred at room temperature for $12 \mathrm{~h}$. After the completion of reaction, DCM $(100 \mathrm{~mL})$ was added and the organic layer was washed with saturated sodium thiosulphate $\mathrm{Na}_{2} \mathrm{~S}_{2} \mathrm{O}_{3}(100 \mathrm{~mL} \times 2)$, brine $(100 \mathrm{~mL} \times 2)$, and dried over $\mathrm{Na}_{2} \mathrm{SO}_{4}$ and filtered. The organic solvent was then removed under vacuum and the residue was purified by flash column chromatography $(2 \%$ EtOAc/hexane $)$ to obtain compound (1.1 g, 63\%). ${ }^{1} \mathrm{H}$ NMR (400 MHz, $\left.\mathrm{CDCl}_{3}\right) \delta 1.34(\mathrm{~s}, 3 \mathrm{H})$, 1.45 (s, 3H), $3.14(\mathrm{~m}, 1 \mathrm{H}), 3.25$ (dd, $J=9.8 \mathrm{~Hz}, 4.7 \mathrm{~Hz}, 1 \mathrm{H}), 3.78$ (dd, $J=8.5 \mathrm{~Hz}, 5.4 \mathrm{~Hz}, 1 \mathrm{H}), 4.14(\mathrm{dd}, J=8.6 \mathrm{~Hz}, 5.9 \mathrm{~Hz}, 1 \mathrm{H}), 4.27$ $(\mathrm{m}, 1 \mathrm{H})$. The ${ }^{1} \mathrm{H}$ NMR was found to be consistent with that reported in the literature. ${ }^{28}$ For large scale $(10 \mathrm{~g})$, column purification was avoided by addition of warm $1.8 \mathrm{M}$ methanolic solution of $\mathrm{ZnCl}_{2}(50 \mathrm{~mL})$ into a DCM solution $(10 \mathrm{~mL})$ of the crude product which resulted in the formation of white shinning crystals of $\mathrm{ZnCl}_{2}\left(\mathrm{Ph}_{3} \mathrm{PO}\right)_{x}{ }^{31}$ after keeping the reaction mixture at room temperature for overnight. The reaction mixture was filtered and concentrated to yield pure product which was used as it for further transformations.

\section{tert-Butyl-O-(tert-butyl)-L-serinate (7)}

To a suspension of $\mathrm{L}$-serine $(5 \mathrm{~g}, 0.047 \mathrm{~mol})$ in tert-butylacetate (121 mL, $0.36 \mathrm{~mol}), 70 \% \mathrm{HCIO}_{4}(4.6 \mathrm{~mL}, 76 \mathrm{~mol})$ was added slowly by dropping funnel at $0{ }^{\circ} \mathrm{C}$. After stirring at room temperature for $6 \mathrm{~h}, 2 \mathrm{~N}$ dil $\mathrm{HCl}(50 \mathrm{~mL})$ was added to reaction mixture and further, basified to $\mathrm{pH} 9$ by the addition of $\mathrm{K}_{2} \mathrm{CO}_{3}$ solution. The product was extracted using DCM $(300 \mathrm{~mL})$ and the organic layer was washed with, water $(200 \mathrm{~mL} \times 2)$, brine $(200 \mathrm{~mL} \times 2)$ and dried over $\mathrm{Na}_{2} \mathrm{SO}_{4}$, filtered and concentrated to afford (S)-tert-butyl 2-amino-3-tert-butoxypropanoate as colorless oil (8.26 g, 80\%). ${ }^{1} \mathrm{H}$ NMR (CDCl3, $\left.300 \mathrm{MHz}\right) \delta 3.58(\mathrm{~m}$, $2 \mathrm{H}), 3.44(\mathrm{~m}, 1 \mathrm{H}), 1.74(\mathrm{~s}, 3 \mathrm{H}), 1.47$ (s, 9H), $1.16(\mathrm{~s}, 9 \mathrm{H}) .{ }^{13} \mathrm{C}$ NMR (CDCl3, $100 \mathrm{MHz}) \delta 173.4,80.9,72.8,63.9,55.6,28.0,27.4$. The ${ }^{1} \mathrm{H}$ NMR and ${ }^{13} \mathrm{C}$ NMR spectra were consistent with that reported in the literature. ${ }^{32}$

\section{$\left(2 R, 2^{\prime} R\right)-3,3^{\prime}$-Disulfanediylbis(2-((tert-butoxycarbonyl)amino) propanoicacid) (15)}

Compound $\mathbf{1 5}$ was synthesized by a modified procedure as reported in the literature to avoid column chromatography on large scale. To a solution of L-cystine $14(2 \mathrm{~g}, 8.32 \mathrm{mmol})$ in water (80 mL), triethylamine $(3.5 \mathrm{~mL}, 24.97 \mathrm{mmol})$ was added followed by di-tert-butyl-dicarbonate $(5.44 \mathrm{~g}, 24.97 \mathrm{mmol})$ and it was stirred at room temperature for $24 \mathrm{~h}$. The reaction was quenched by adding $10 \% \mathrm{HCl}$ solution $(15 \mathrm{~mL})$ at $0{ }^{\circ} \mathrm{C}$. The product was precipitated out as a white solid which was filtered and washed with cold distilled water to obtain pure compound $15(2.7 \mathrm{~g}, 74 \%) .{ }^{1} \mathrm{H}$ NMR $(\mathrm{CDCl} 3,300 \mathrm{MHz}) \delta 5.6(\mathrm{~m}, 1 \mathrm{H}), 4.5(\mathrm{~m}$, $J=4.8 \mathrm{~Hz}, 2 \mathrm{H}), 3.24(\mathrm{~m}, 4 \mathrm{H}), 1.45(\mathrm{~s}, 18 \mathrm{H})$. The ${ }^{1} \mathrm{H}$ NMR was consistent with that reported in the literature. ${ }^{33}$
Di-tert-butyl-2,2' $-\left(\left(\left(2 R, 2^{\prime} R\right)-3,3^{\prime}\right.\right.$-disulfanediylbis(2-((tertbutoxycarbonyl)amino)propanoyl))bis(azanediyl))(2S,2'S)bis(3-(tert-butoxy)propanoate) (16)

To a solution of $N \alpha, N \alpha^{\prime}$-di-Boc-cystine $15(0.69 \mathrm{~g}, 1.58 \mathrm{mmol})$ in anhydrous DMF were added $\mathrm{H}-\mathrm{Ser}\left({ }^{t} \mathrm{Bu}\right)-\mathrm{O}{ }^{t} \mathrm{Bu} \cdot \mathrm{HCl} 7(0.84 \mathrm{~g}$, $3.31 \mathrm{mmol})$, HOBt $(0.513 \mathrm{~g}, 3.31 \mathrm{mmol})$, and $\mathrm{Et}_{3} \mathrm{~N}(0.46 \mathrm{~mL}$, $3.31 \mathrm{mmol}$ ). The reaction mixture was stirred at $0{ }^{\circ} \mathrm{C}$ for $30 \mathrm{~min}$, followed by addition of EDCI $(0.24 \mathrm{~g}, 1.58 \mathrm{mmol})$ at $0{ }^{\circ} \mathrm{C}$. The reaction mixture was allowed to come to room temperature and stirred for $6 \mathrm{~h}$. After completion of reaction, the solvent was evaporated under reduced pressure and residue obtained was dissolved in ethyl acetate $(250 \mathrm{~mL})$. It was washed with water $(150 \mathrm{~mL} \times 2)$, brine $(150 \mathrm{~mL} \times 1)$. The organic layer was dried over anhydrous $\mathrm{Na}_{2} \mathrm{SO}_{4}$, filtered, and evaporated under reduced pressure to obtain crude product which was purified using column chromatography $(50 \%$ EtOAc/hexane) to obtain compound 16 (1.12 g, 85\%). ${ }^{1} \mathrm{H}$ NMR $\left(500 \mathrm{MHz} \mathrm{CDCl}_{3}\right) \delta 7.35(\mathrm{~s}, 2 \mathrm{H}), 5.69(\mathrm{~s}, 2 \mathrm{H}), 4.71-4.50(\mathrm{~m}, 4 \mathrm{H})$, $3.77(\mathrm{dd}, J=8.8,3.4 \mathrm{~Hz}, 2 \mathrm{H}), 3.55(\mathrm{dd}, J=8.8,3.4 \mathrm{~Hz}, 2 \mathrm{H})$, 3.18-3.06 (m, 4H), 1.46 (s, 36H), 1.14 (s, 9H). ${ }^{13} \mathrm{C}$ NMR (126 $\left.\mathrm{MHz}, \mathrm{CDCl}_{3}\right) \delta 170.03,168.95,155.39,81.77,80.16,73.35$, $62.08,53.54,43.22,28.42,28.02,27.35$. MS (ESI) calculated for $[\mathrm{M}+\mathrm{Na}]^{+} \mathrm{C}_{38} \mathrm{H}_{70} \mathrm{~N}_{4} \mathrm{NaO}_{12} \mathrm{~S}_{2}{ }^{+} \mathrm{m} / z$ 861.43, found 861.44. For large scale, compound $\mathbf{1 6}$ was used without column chromatography after precipitation as discussed in the result and discussion section.

tert-Butyl- $N$-( $N$-(tert-butoxycarbonyl)-S-(( $R$-2,2-dimethyl-1,3dioxolan-4-yl)methyl)-L-cysteinyl)-O-(tert-butyl)-L-serinate (18)

To a solution of compound $16(1 \mathrm{~g}, 1.29 \mathrm{mmol})$ in DCM (20 $\mathrm{mL})$ and water $(1 \mathrm{~mL})$, tributylphosphine $(50 \%$ solution in EtOAc, $964 \mu \mathrm{L}, 3.86 \mathrm{mmol}$ ) was added and the reaction mixture was stirred at room temperature for 30 minutes. After the completion of the reaction, the solvent was removed under reduced pressure to obtain the crude product 17 (720 mg, 74\%). The small amount of crude product 17 was column purified for the analysis. ${ }^{1} \mathrm{H}$ NMR $\left(500 \mathrm{MHz}, \mathrm{CDCl}_{3}\right)$ $\delta 6.90(\mathrm{~d}, J=7.9 \mathrm{~Hz}, 1 \mathrm{H}), 5.50(\mathrm{~d}, J=6.8 \mathrm{~Hz}, 1 \mathrm{H}), 4.54(\mathrm{dt}, J=$ 8.0, $2.8 \mathrm{~Hz}, 1 \mathrm{H}), 4.37$ (s, $1 \mathrm{H}), 3.79(\mathrm{dd}, J=8.8,2.9 \mathrm{~Hz}, 1 \mathrm{H})$, $3.55(\mathrm{dd}, J=8.8,3.0 \mathrm{~Hz}, 1 \mathrm{H}), 3.08(\mathrm{ddd}, J=13.9,8.0,4.2 \mathrm{~Hz}$, 1H), 2.75 (ddd, $J=13.9,10.2,6.3 \mathrm{~Hz}, 1 \mathrm{H}), 1.77(\mathrm{t}, J=8.8 \mathrm{~Hz}$, 1H), 1.46 (s, 18H), $1.14(\mathrm{~s}, 9 \mathrm{H}) .{ }^{13} \mathrm{C} \mathrm{NMR}\left(126 \mathrm{MHz}, \mathrm{CDCl}_{3}\right.$ ) $\delta$ 169.55, 168.95, 155.20, 82.11, 80.32, 73.22, 61.81, 55.57, $53.52,28.30,28.01,27.47,27.35$. To the solution of crude compound 17 (700 mg, $1.67 \mathrm{mmol})$ in DMF (10 mL) were added $\mathrm{K}_{2} \mathrm{CO}_{3}(346 \mathrm{mg}, 2.51 \mathrm{mmol})$ and compound $5(1.01 \mathrm{~g}$, $4.17 \mathrm{mmol})$. The reaction mixture was stirred at room temperature for $2 \mathrm{~h}$. After completion of the reaction, reaction mixture was poured onto crushed ice with stirring and product was extracted with DCM $(250 \mathrm{~mL})$, followed by washings with water $(150 \mathrm{~mL} \times 2)$, brine $(150 \mathrm{~mL} \times 2)$. The organic layer was finally concentrated to obtain crude product which was purified using column chromatography (25\% EtOAc/hexane) to obtain compound 18 (800 mg, 90\%). ${ }^{1} \mathrm{H}$ NMR $\left(500 \mathrm{MHz}, \mathrm{CDCl}_{3}\right) \delta 7.06(\mathrm{~d}, J=8.0 \mathrm{~Hz}, 1 \mathrm{H}), 5.50(\mathrm{~s}$, $1 \mathrm{H}), 4.54(\mathrm{dt}, J=8.0,2.9 \mathrm{~Hz}, 1 \mathrm{H}), 4.35-4.26(\mathrm{~m}, 2 \mathrm{H}), 4.10(\mathrm{dd}$, 
$J=8.3,6.1 \mathrm{~Hz}, 1 \mathrm{H}), 3.79(\mathrm{dd}, J=8.8,2.9 \mathrm{~Hz}, 1 \mathrm{H}), 3.70(\mathrm{dd}, J=$ 8.3, $6.6 \mathrm{~Hz}, 1 \mathrm{H}), 3.53$ (dd, $J=8.8,3.0 \mathrm{~Hz}, 1 \mathrm{H}), 3.05(\mathrm{dd}, J=$ 13.9, $5.9 \mathrm{~Hz}, 1 \mathrm{H}), 2.94(\mathrm{dd}, J=13.9,6.3 \mathrm{~Hz}, 1 \mathrm{H}), 2.82(\mathrm{dd}, J=$ 13.5, $6.2 \mathrm{~Hz}, 1 \mathrm{H}), 2.71(\mathrm{dd}, J=13.5,6.1 \mathrm{~Hz}, 1 \mathrm{H}), 1.46$ (d, $J=$ $1.7 \mathrm{~Hz}, 18 \mathrm{H}), 1.44$ (s, 3H), 1.36 (s, 3H), 1.15 (s, 9H). ${ }^{13} \mathrm{C}$ NMR $\left(126 \mathrm{MHz}, \mathrm{CDCl}_{3}\right) \delta 170.18,168.91,155.28,109.67,81.94$, 80.17, 75.59, 73.13, 68.74, 61.99, 54.07, 53.49, 35.56, 35.32, 28.30, 28.01, 27.35, 26.87, 25.56. MS (ESI) calculated for [M + $\mathrm{Na}]^{+} \mathrm{C}_{25} \mathrm{H}_{46} \mathrm{~N}_{2} \mathrm{NaO}_{8} \mathrm{~S}^{+} \mathrm{m} / z$ 557.28, found 558.26.

tert-Butyl- $N-(N-($ tert-butoxycarbonyl)-S-((R)-2,3dihydroxypropyl)-L-cysteinyl)-O-(tert-butyl)-L-serinate (19)

The compound 18 (2.9 g) was dissolved in $70 \%$ acetic acid (30 $\mathrm{mL}, \mathrm{AcOH}:$ water $=7: 3)$ and the reaction mixture was stirred at room temperature for $16 \mathrm{~h}$. After completion of the reaction, the reaction mixture was diluted with EtOAc $(350 \mathrm{~mL})$ and washed with $10 \%$ sodium bicarbonate $(200 \mathrm{~mL} \times 2)$, water $(200 \mathrm{~mL} \times 2)$ and brine $(200 \mathrm{~mL})$ and organic layer was concentrated under reduced pressure to yield crude product which was purified using column chromatography $(5 \% \mathrm{MeOH} /$ DCM) to obtain compound 19 (2.5 g, 96\%). ${ }^{1} \mathrm{H}$ NMR (500 MHz, $\left.\mathrm{CDCl}_{3}\right) \delta 7.23(\mathrm{~d}, J=7.7 \mathrm{~Hz}, 1 \mathrm{H}), 5.63(\mathrm{~d}, J=8.1 \mathrm{~Hz}, 1 \mathrm{H}), 4.57(\mathrm{dt}$, $J=8.1,2.9 \mathrm{~Hz}, 1 \mathrm{H}), 4.42(\mathrm{~d}, J=5.8 \mathrm{~Hz}, 1 \mathrm{H}), 3.89-3.83(\mathrm{~m}, 1 \mathrm{H})$, $3.81-3.78(\mathrm{~m}, 1 \mathrm{H}), 3.70(\mathrm{dd}, J=11.3,3.6 \mathrm{~Hz}, 2 \mathrm{H}), 3.60(\mathrm{dd}, J=$ $11.3,6.2 \mathrm{~Hz}, 1 \mathrm{H}), 3.55$ (dd, $J=8.9,3.0 \mathrm{~Hz}, 1 \mathrm{H}), 3.00(\mathrm{dd}, J=14.1$, $5.6 \mathrm{~Hz}, 1 \mathrm{H}), 2.91(\mathrm{dd}, J=14.1,6.7 \mathrm{~Hz}, 1 \mathrm{H}), 2.78(\mathrm{~m}, 2 \mathrm{H}), 1.47(\mathrm{~s}$, 9H), 1.45 (s, 9H), $1.16(\mathrm{~s}, 9 \mathrm{H}) .{ }^{13} \mathrm{C} \mathrm{NMR}\left(126 \mathrm{MHz}, \mathrm{CDCl}_{3}\right.$ ) $\delta 170.23,169.20,155.56,82.26,80.36,73.34,71.10,65.23,62.02$, 53.49, 35.93, 28.30, 28.02, 27.34. MS (ESI) calculated for [M+ $\mathrm{Na}]^{+} \mathrm{C}_{22} \mathrm{H}_{37} \mathrm{~N}_{2} \mathrm{NaO}_{8} \mathrm{~S}^{+} m / z 517.25$, found 517.23. For large scale, compound 19 was used further without any column purification.

$((R)-3-((R)-2-($ tert-Butoxycarbonylamino)-3-((S)-1,3-di-tertbutoxy-1-oxopropan-2-ylamino)-3-oxopropylthio)propane-1,2diyldipalmitate) (20)

To a solution of compound $19(650 \mathrm{mg}, 1.31 \mathrm{mmol})$ in anhydrous DCM $(15 \mathrm{~mL})$ were added $\mathrm{Et}_{3} \mathrm{~N}(733 \mu \mathrm{L}, 5.26 \mathrm{mmol})$ and a catalytic amount of DMAP $(20 \mathrm{~mol} \%)$. The reaction mixture was stirred at $0{ }^{\circ} \mathrm{C}$ for 30 minutes. Palmitoyl chloride $(1.2 \mathrm{~mL}$, $3.94 \mathrm{mmol}$ ) was then added at $0{ }^{\circ} \mathrm{C}$, followed by stirring at room temperature for $12 \mathrm{~h}$. After completion of the reaction, the reaction mixture was thoroughly washed with water $(250 \mathrm{~mL} \times 2)$, saturated sodium bicarbonate solution $(250 \mathrm{~mL}$ $\times 2)$, brine $(200 \mathrm{~mL} \times 1)$. The organic layer was dried over anhydrous $\mathrm{Na}_{2} \mathrm{SO}_{4}$, filtered and, evaporated under reduced pressure to obtain crude product which was purified using column chromatography $(20 \%$ EtOAc/hexane $)$ to obtain compound 20 (880 mg, 68\%). ${ }^{1} \mathrm{H}$ NMR (500 MHz, $\left.\mathrm{CDCl}_{3}\right) \delta 7.04$ $(\mathrm{d}, J=8.0 \mathrm{~Hz}, 1 \mathrm{H}), 5.40(\mathrm{~d}, J=6.1 \mathrm{~Hz}, 1 \mathrm{H}), 5.18(\mathrm{dd}, J=5.7$, $3.7 \mathrm{~Hz}, 1 \mathrm{H}), 4.53$ (dt, $J=8.1,2.9 \mathrm{~Hz}, 1 \mathrm{H}), 4.33(\mathrm{dd}, J=11.9$, $3.5 \mathrm{~Hz}, 2 \mathrm{H}), 4.17$ (dd, $J=11.9,5.9 \mathrm{~Hz}, 1 \mathrm{H}), 3.79(\mathrm{dd}, J=8.8$, $2.9 \mathrm{~Hz}, 1 \mathrm{H}), 3.53(\mathrm{dd}, J=8.8,3.0 \mathrm{~Hz}, 1 \mathrm{H}), 2.96(\mathrm{~d}, J=6.3 \mathrm{~Hz}$, $2 \mathrm{H}), 2.82(\mathrm{~d}, J=6.0 \mathrm{~Hz}, 2 \mathrm{H}), 2.32(\mathrm{ddd}, J=12.3,6.7,3.0 \mathrm{~Hz}$, $4 \mathrm{H}), 1.67-1.56(\mathrm{~m}, 5 \mathrm{H}), 1.46$ (d, $J=3.5 \mathrm{~Hz}, 18 \mathrm{H}), 1.27$ (d, $J=$ $15.1 \mathrm{~Hz}, 48 \mathrm{H}), 1.15$ (s, 9H), 0.88 (t, $J=7.0 \mathrm{~Hz}, 6 \mathrm{H}) .{ }^{13} \mathrm{C}$ NMR $\left(126 \mathrm{MHz}, \mathrm{CDCl}_{3}\right) \delta 173.50,173.23,170.19,169.03,155.36$, 82.06, 80.28, 73.26, 70.45, 63.63, 62.09, 54.12, 53.64, 35.77, $34.43,34.23,33.28,32.07,29.85,29.81,29.66,29.51,29.46$, 29.45, 29.29, 29.28, 28.43, 27.48, 25.04, 25.02, 22.84, 14.27. MS (ESI) calculated for $[\mathrm{M}+\mathrm{Na}]^{+} \mathrm{C}_{54} \mathrm{H}_{102} \mathrm{~N}_{2} \mathrm{NaO}_{10} \mathrm{~S}^{+}, \mathrm{m} / z$ 993.71, found 993.19.

\section{$S$-((R)-2,3-Bis(palmitoyloxy)propyl)- $N$-(tert-butoxycarbonyl)- L-cysteinyl-L-serine (22)}

The compound 20 (500 $\mathrm{mg}, 0.53 \mathrm{mmol}$ ) was stirred with trifluoroacetic acid (TFA, $8 \mathrm{~mL}$ ) for 30 minutes at $25{ }^{\circ} \mathrm{C}$, followed by purging nitrogen gas. After that remaining TFA was co-evaporated with $\mathrm{CHCl}_{3}(5 \mathrm{~mL} \times 3)$ and DCM $(5 \mathrm{~mL} \times 2)$ in order to get solid crude compound which was purified by column chromatography $(10 \% \mathrm{MeOH} / \mathrm{DCM})$ to get compound 21 (350 mg, 89\%). MS (ESI) calculated for $[\mathrm{M}+\mathrm{H}]^{+}$ $\mathrm{C}_{41} \mathrm{H}_{78} \mathrm{~N}_{2} \mathrm{O}_{8} \mathrm{~S} m / z$ 758.54, found 758.28. To a solution of compound 21 (286 mg, $0.32 \mathrm{mmol}$ ) in DCM, di-tert-butyl dicarbonate (246 mg, $1.31 \mathrm{mmol}) \mathrm{Et}_{3} \mathrm{~N}(133 \mu \mathrm{L}, 0.92 \mathrm{mmol})$ were added and the reaction mixture was stirred for $4 \mathrm{~h}$. The reaction mixture was diluted with DCM $(300 \mathrm{~mL})$ and organic layer was sequentially washed with water $(250 \mathrm{~mL} \times 2)$, saturated sodium bicarbonate solution $(250 \mathrm{~mL} \times 2)$, brine $(200 \mathrm{~mL} \times 1)$. The organic layer was dried over anhydrous sodium sulfate, filtered and evaporated under reduced pressure to obtain the crude product which was purified using column chromatography (5\% $\mathrm{MeOH} / \mathrm{DCM})$ to afford compound 22 (188 mg, 67\%). ${ }^{1} \mathrm{H}$ NMR (500 $\mathrm{MHz}, \mathrm{CDCl}_{3}$ ) $\delta$ 12.17-11.77 (m, 1H), 7.59-7.48 (m, 1H), 5.67-5.54 (m, 1H), $5.20-5.13(\mathrm{~m}, 1 \mathrm{H}), 4.63-4.53(\mathrm{~m}, 1 \mathrm{H}), 4.44-4.36(\mathrm{~m}, 1 \mathrm{H}), 4.32$ $(\mathrm{s}, 1 \mathrm{H}), 4.14(\mathrm{~s}, 1 \mathrm{H}), 4.09-4.01(\mathrm{~m}, 1 \mathrm{H}), 3.96-3.82(\mathrm{~m}, 1 \mathrm{H})$, $3.10(\mathrm{~s}, 1 \mathrm{H}), 3.06-2.88(\mathrm{~m}, 2 \mathrm{H}), 2.76(\mathrm{~s}, 2 \mathrm{H}), 2.29(\mathrm{~d}, J=$ $7.4 \mathrm{~Hz}, 4 \mathrm{H}), 1.65-1.55(\mathrm{~m}, 4 \mathrm{H}), 1.43(\mathrm{~s}, 9 \mathrm{H}), 1.21(\mathrm{~s}, 48 \mathrm{H}), 0.86$ (s, 6H). ${ }^{13} \mathrm{C}$ NMR $\left(126 \mathrm{MHz} \mathrm{CDCl}_{3}\right) \delta 173.89,173.74,171.04$, 156.02, 80.96, 77.41, 77.16, 76.91, 70.53, 63.84, 62.82, 55.31, $54.04,45.82,35.16,34.50,34.25,32.91,32.08,29.87,29.83$, 29.70, 29.68, 29.53, 29.48, 29.32, 29.29, 28.42, 25.06, 25.02, 22.85, 14.28, 8.69. MS (ESI) calculated for $[\mathrm{M}+\mathrm{Na}]^{+} \mathrm{C}_{46} \mathrm{H}_{86^{-}}$ $\mathrm{N}_{2} \mathrm{NaO}_{10} \mathrm{~S}^{+} m / z 881.58$, found 881.58.

\section{tert-Butyl- $N^{2}-\left(\left(\left(9 H\right.\right.\right.$-fluoren-9-yl)methoxy)carbonyl)- $N^{6}-($ tert- butoxycarbonyl)-L-lysinate (Fmoc-Lys(Boc)-O $\left.{ }^{t} \mathrm{Bu}\right)(24)$}

The compound $\mathbf{2 4}$ was synthesized using precursor FmocLys(Boc)-OH $23(5.0$ g, $10.7 \mathrm{mmol})$ using a reported protocol. ${ }^{38}$ Yield (3.91 g, 70\%). ${ }^{1} \mathrm{H}$ NMR (400 $\mathrm{MHz}, \mathrm{CDCl}_{3}$ ); $\delta 7.76(\mathrm{~d}, J=7.5 \mathrm{~Hz}, 2 \mathrm{H}), 7.60(\mathrm{~d}, J=7.3 \mathrm{~Hz}, 2 \mathrm{H}), 7.40(\mathrm{t}, J=$ $7.5 \mathrm{~Hz}, 2 \mathrm{H}), 7.31(\mathrm{t}, J=7.5 \mathrm{~Hz}, 2 \mathrm{H}), 5.36(\mathrm{~d}, J=8 \mathrm{~Hz}, 1 \mathrm{H}), 4.37-$ $4.42(\mathrm{~m}, 2 \mathrm{H}), 4.20-4.27(\mathrm{~m}, 2 \mathrm{H}), 3.10(\mathrm{t}, J=6.6 \mathrm{~Hz}, 2 \mathrm{H}), 1.77-$ $1.86(\mathrm{~m}, 4 \mathrm{H}), 1.47(\mathrm{~s}, 9 \mathrm{H}), 1.43(\mathrm{~s}, 11 \mathrm{H})$.

\section{tert-Butyl- $N^{6}$-(tert-butoxycarbonyl)-L-lysinate (H-Lys(Boc)- $\left.\mathrm{O}^{t} \mathrm{Bu}\right)(25)$}

The compound 25 (4.0 g, $7.62 \mathrm{mmol})$ was synthesized as reported in the literature ${ }^{38}$ and confirmed by mass spectrometric analysis. Yield $(1.75 \mathrm{~g}, 76 \%)$. MS (ESI) calculated for $[\mathrm{M}+\mathrm{H}]^{+}$ $\mathrm{C}_{15} \mathrm{H}_{31} \mathrm{~N}_{2} \mathrm{O}_{4}{ }^{+} \mathrm{m} / z$ 303.22, found 303.53. 
tert-Butyl- $N^{2}-\left(N^{2}-\left(\left(\left(9 H\right.\right.\right.\right.$-fluoren-9-yl)methoxy)carbonyl)- $N^{6}$ (tert-butoxycarbonyl)-L-lysyl)- $N^{6}$-(tert-butoxycarbonyl)L-lysinate (Fmoc-Lys(Boc)-Lys(Boc)-O ${ }^{t} \mathrm{Bu}$ ) (26)

The compound 26 (1.6 g, $5.2 \mathrm{mmol})$ was obtained using similar procedure as reported and by using pyridine instead of $N, N$-diisopropylethylamine (DIPEA) ${ }^{39}$ Yield $(3.08 \mathrm{~g}, 87 \%) .{ }^{1} \mathrm{H}$ NMR $(400 \mathrm{MHz}$, $\left.\mathrm{CDCl}_{3}\right) \delta 7.75(\mathrm{~d}, J=7.5 \mathrm{~Hz}, 2 \mathrm{H}), 7.59(\mathrm{~d}, J=7.4 \mathrm{~Hz}, 2 \mathrm{H}), 7.39(\mathrm{t}, J=$ $7.4 \mathrm{~Hz}, 2 \mathrm{H}), 7.30$ (m, 2H), 6.57 (bs, 1H), 5.59 (bs, 1H), 4.67 (bs, 2H), 4.37-4.46 (m, 3H), 4.11-4.23 (m, 2H), 3.05-3.11 (m, 4H), $1.83(\mathrm{~m}$, $2 \mathrm{H}), 1.71(\mathrm{~m}, 4 \mathrm{H}), 1.43(\mathrm{~m}, 32 \mathrm{H}), 1.25(\mathrm{~m}, 2 \mathrm{H}), 1.19-1.21(\mathrm{~m}, 2 \mathrm{H})$.

tert-Butyl- $N^{6}$-(tert-butoxycarbonyl)- $N^{2}-\left(N^{6}-(\right.$ tertbutoxycarbonyl)---lysyl)-L-lysinate (H-Lys(Boc)-Lys(Boc)-O ${ }^{t}$ Bu) (27)

The deprotection of Fmoc-Lys(Boc)-Lys(Boc)-O ${ }^{t}$ Bu 26 (500 mg, $0.66 \mathrm{mmol}$ ) was carried out as described for compound 24 to afford compound $27 .{ }^{39}$ Yield (334.8 mg, 95\%). ${ }^{1} \mathrm{H}$ NMR (400 $\left.\mathrm{MHz}, \mathrm{CDCl}_{3}\right) \delta 7.71(\mathrm{~d}, J=7.0 \mathrm{~Hz}, 1 \mathrm{H}), 4.69$ (bs, $\left.2 \mathrm{H}\right), 4.42-4.47$ (m, $1 \mathrm{H}), 3.37-3.40(\mathrm{~m}, 1 \mathrm{H}), 3.09-3.12(\mathrm{~m}, 4 \mathrm{H}), 1.80(\mathrm{~m}, 4 \mathrm{H})$, 1.45-1.75 (m, 8H), $1.45(\mathrm{~s}, 9 \mathrm{H}), 1.42(\mathrm{~s}, 18 \mathrm{H})$. MS (ESI) calculated for $[\mathrm{M}+\mathrm{H}]^{+} \mathrm{C}_{26} \mathrm{H}_{51} \mathrm{~N}_{4} \mathrm{O}_{7} \mathrm{~m} / z$ 531.37, found 531.40.

tert-Butyl- $N^{2}-\left(N^{2}-\left(N^{2}-\left(\left(\left(9 H\right.\right.\right.\right.\right.$-fluoren-9-yl)methoxy)carbonyl)- $N^{6}-$ (tert-butoxycarbonyl)-L-lysyl)- $N^{6}$-(tert-butoxycarbonyl)-L-lysyl)$N^{6}$-(tert-butoxycarbonyl)--L-lysinate (Fmoc-Lys(Boc)-Lys(Boc)Lys(Boc)-O $\left.{ }^{t} \mathrm{Bu}\right)(28)$

H-Lys(Boc)-Lys(Boc)-O ${ }^{t}$ Bu 27 (400 mg, $0.75 \mathrm{mmol}$ ) and FmocLys-OH $23(317.8 \mathrm{mg}, 0.678 \mathrm{mmol})$ were dissolved in $5 \mathrm{~mL}$ of DMF at $0{ }^{\circ} \mathrm{C}$ at inert atmosphere. HOBt $(51 \mathrm{mg}, 0.376 \mathrm{mmol})$ and pyridine $(0.12 \mathrm{~mL}, 1.5 \mathrm{mmol})$ were further added to the reaction mixture at $0{ }^{\circ} \mathrm{C}$. After 10 minutes stirring, EDCI (216.5 mg, $1.13 \mathrm{mmol}$ ) was added to the reaction mixture and reaction was allowed to warm to room temperature and stirred for $6 \mathrm{~h}$. The completion of the reaction was monitored by TLC. The reaction mixture was dissolved in water $(100 \mathrm{~mL})$ and EtOAc $(200 \mathrm{~mL})$ and the organic phase was washed successively with $5 \%$ citric acid $(50 \mathrm{~mL} \times 2), \mathrm{NaHCO}_{3}(50 \mathrm{~mL} \times 2)$ and brine $(50 \mathrm{~mL} \times 2)$. The crude product obtained was purified by column chromatography $(2 \% \mathrm{MeOH} / \mathrm{DCM})$ to obtain compound $28(547 \mathrm{mg}, 74 \%) .{ }^{1} \mathrm{H}$ NMR $\left(400 \mathrm{MHz}, \mathrm{CDCl}_{3}\right) \delta 7.74-$ $7.76(\mathrm{~d}, J=7.5 \mathrm{~Hz}, 2 \mathrm{H}), 7.59-7.60(\mathrm{~d}, J=7.0 \mathrm{~Hz}, 2 \mathrm{H}), 7.38(\mathrm{t}, J=$ $7.4 \mathrm{~Hz}, 2 \mathrm{H}), 7.30(\mathrm{t}, J=7.2 \mathrm{~Hz}, 2 \mathrm{H}), 6.94(\mathrm{~m}, 1 \mathrm{H}), 6.83(\mathrm{~m}, 1 \mathrm{H})$, $5.81(\mathrm{~m}, 1 \mathrm{H}), 4.93(\mathrm{~m}, 1 \mathrm{H}), 4.83(\mathrm{~m}, 1 \mathrm{H}), 4.39(\mathrm{~m}, 3 \mathrm{H}), 4.20(\mathrm{t}, J=$ $7.0 \mathrm{~Hz}, 2 \mathrm{H}), 3.05(\mathrm{~m}, 5 \mathrm{H}), 2.06(\mathrm{~m}, 2 \mathrm{H}), 1.84(\mathrm{~m}, 3 \mathrm{H}), 1.65(\mathrm{~m}$, $3 \mathrm{H}), 1.42(\mathrm{~m}, 44 \mathrm{H}) .{ }^{13} \mathrm{C}$ NMR $\delta 171.23,156.31,156.19,141.26$, 127.72, 127.11, 125.14, 119.96, 82.10, 79.10, 77.25, 67.17, 54.85, $52.68,47.10,40.11,39.94,39.78,32.06,31.76,29.48,28.47$, $28.01,22.53,22.32$. MS (ESI) calculated for $[\mathrm{M}+\mathrm{Na}]^{+}$ $\mathrm{C}_{52} \mathrm{H}_{80} \mathrm{~N}_{6} \mathrm{NaO}_{12}{ }^{+} \mathrm{m} / \mathrm{z}$ 1003.57, found 1003.54.

tert-Butyl- $N^{6}$-(tert-butoxycarbonyl)- $N^{2}-\left(N^{6}-(\right.$ tertbutoxycarbonyl)- $N^{2}$-( $N^{6}$-(tert-butoxycarbonyl)-L-lysyl)-L-lysyl)-Llysinate (H-Lys(Boc)-Lys(Boc)-Lys(Boc)-O $\left.{ }^{t} \mathrm{Bu}\right)(29)$

Fmoc-Lys(Boc)-Lys(Boc)-Lys(Boc)-O ${ }^{t}$ Bu 28 (450 mg, $0.458 \mathrm{mmol}$ ) was dissolved in a solution of $20 \%$ of piperidine in DMF ( $3 \mathrm{~mL}$ ) and stirred for $1 \mathrm{~h}$. After completion of reaction, the solvent was evaporated and the crude product obtained was purified by column chromatography $(10 \% \quad \mathrm{MeOH} / \mathrm{DCM})$ to obtain compound $29(300 \mathrm{mg}, 86 \%)$. MS (ESI) calculated for $[\mathrm{M}+\mathrm{H}]^{+}$ $\mathrm{C}_{37} \mathrm{H}_{71} \mathrm{~N}_{6} \mathrm{O}_{10} \mathrm{~m} / \mathrm{z} 759.52$, found 759.24 .

tert-Butyl-(2R,5S)-5-((2R,5S)-5-((( $9 H$-fluoren-9-yl)methoxy) carbonyl)amino)-9-((tert-butoxycarbonyl)amino)-2-(4-((tertbutoxycarbonyl)amino)butyl)-4-oxononanamido)-9-((tertbutoxycarbonyl)amino)-2-(4-((tert-butoxycarbonyl)amino) butyl)-4-oxononanoate (Fmoc-Lys(Boc)-Lys(Boc)-Lys(Boc)Lys(Boc)- $\left.{ }^{t}{ }^{B u}\right)(30)$

$\mathrm{NH}_{2}$-Lys(Boc)-Lys(Boc)-Lys(Boc)-O ${ }^{t} \mathrm{Bu} 29$ (300 mg, $0.40 \mathrm{mmol}$ ) and Fmoc-Lys-OH $23(166.7 \mathrm{mg}, 0.36 \mathrm{mmol})$ were dissolved in $10 \mathrm{~mL}$ of DMF at $0{ }^{\circ} \mathrm{C}$ under nitrogen atmosphere. HOBt $(26.7 \mathrm{mg}, 0.197 \mathrm{mmol})$ and pyridine $(63.7 \mu \mathrm{L}, 0.79 \mathrm{mmol})$ were further added to the reaction mixture under cooling condition. After 10 minutes stirring, EDCI $(113.6 \mathrm{mg}, 0.59 \mathrm{mmol})$ was added to the reaction mixture and reaction was allowed to warm to room temperature and stirred for $6 \mathrm{~h}$. The completion of the reaction was monitored by TLC. The reaction mixture was dissolved in water $(150 \mathrm{~mL})$ and EtOAc $(200 \mathrm{~mL})$ and the organic phase was washed successively with $5 \%$ citric acid $(50 \mathrm{~mL} \times 2)$, $\mathrm{NaHCO}_{3}(50 \mathrm{~mL} \times 2)$ and brine $(50 \mathrm{~mL} \times 2)$. The crude product obtained was purified by column chromatography on $60-120$ mesh silica gel in $4 \% \mathrm{MeOH} / \mathrm{DCM}$ to obtain compound 30 (301 mg, 63\%). ${ }^{1} \mathrm{H}$ NMR $\left(400 \mathrm{MHz}, \mathrm{CDCl}_{3}\right) \delta 9.08(\mathrm{bs}, 1 \mathrm{H}), 8.54$ (bs, $1 \mathrm{H}), 7.75(\mathrm{~d}, J=7.5 \mathrm{~Hz}, 2 \mathrm{H}), 7.59-7.61(\mathrm{~d}, J=6.4 \mathrm{~Hz}, 2 \mathrm{H})$, $7.38(\mathrm{t}, J=7.4 \mathrm{~Hz}, 2 \mathrm{H}), 7.29(\mathrm{~m}, 2 \mathrm{H}), 6.98(\mathrm{~m}, 1 \mathrm{H}), 6.76(\mathrm{~m}, 1 \mathrm{H})$, 5.93-6.08 (m, 2H), $5.37(\mathrm{~m}, 1 \mathrm{H}), 4.96(\mathrm{~m}, 1 \mathrm{H}), 4.82-4.86(\mathrm{~m}, 1 \mathrm{H})$, 4.32-4.56 (m, 6H), 4.19-4.22 (m, 2H), 2.88-3.07 (m, 9H), 1.85 $(\mathrm{m}, 6 \mathrm{H}), 1.59-1.71(\mathrm{~m}, 7 \mathrm{H}), 1.43(\mathrm{~m}, 67 \mathrm{H}) .{ }^{13} \mathrm{C}$ NMR $(100 \mathrm{MHz}$, $\left.\mathrm{CDCl}_{3}\right) \delta 171.34,156.44,141.39,127.78,127.19,125.37,120.0$, $60.55,47.32,28.62,28.13,22.83,21.21,14.34$. MS (ESI) calculated for $[\mathrm{M}+\mathrm{Na}]^{+} \mathrm{C}_{63} \mathrm{H}_{100} \mathrm{~N}_{8} \mathrm{NaO}_{15}{ }^{+} \mathrm{m} / \mathrm{z}$ 1231.72, found 1231.63.

tert-Butyl-(2R,5S)-5-((2R,5S)-5-amino-9-((tert-butoxycarbonyl) amino)-2-(4-((tert-butoxycarbonyl)amino)butyl)-4oxononanamido)-9-((tert-butoxycarbonyl)amino)-2-(4-((tertbutoxycarbonyl)amino)butyl)-4-oxononanoate (H-Lys(Boc)$\left.\operatorname{Lys}(\mathrm{Boc})-\operatorname{Lys}(\mathrm{Boc})-\operatorname{Lys}(\mathrm{Boc})-\mathrm{O}^{t} \mathrm{Bu}\right)(31)$

Fmoc-Lys(Boc)-Lys(Boc)-Lys(Boc)-Lys(Boc)-O ${ }^{t} \mathrm{Bu} \quad 30$ (300 mg, $0.248 \mathrm{mmol}$ ) was dissolved in a solution of $20 \%$ of piperidine in DMF $(2 \mathrm{~mL})$ and stirred for $1 \mathrm{~h}$. The solvent was evaporated and the crude product obtained was purified by column chromatography on $60-120$ mesh silica gel in $15 \% \mathrm{MeOH} / \mathrm{DCM}$ to obtain compound 31 (150 mg, 61\%). MS (ESI) calculated for [M $+\mathrm{H}]^{+} \mathrm{C}_{48} \mathrm{H}_{91} \mathrm{~N}_{8} \mathrm{O}_{13}{ }^{+} \mathrm{m} / \mathrm{z}$ 987.67, found 987.65.

$S$-(2,3-Bis(palmitoyloxy)propyl)-cysteinyl-seryl-lysyl-lysyl-lysyllysine (2)

To a solution of compound $22(100 \mathrm{mg}, 0.12 \mathrm{mmol})$ in anhydrous DMF were added $\mathrm{H}$-[Lys(Boc) $]_{4}-\mathrm{O}^{t} \mathrm{Bu} 31(126 \mathrm{mg}, 0.13$ $\mathrm{mmol})$, HOBt ( $16 \mathrm{mg}, 0.12 \mathrm{mmol})$, and $\mathrm{Et}_{3} \mathrm{~N}(34 \mu \mathrm{L}, 0.24 \mathrm{mmol})$. The reaction mixture was stirred at $0{ }^{\circ} \mathrm{C}$ for $30 \mathrm{~min}$, followed by addition of EDCI $(69.0 \mathrm{mg}, 0.36 \mathrm{mmol})$ at $0{ }^{\circ} \mathrm{C}$. The reaction 
mixture was further stirred at room temperature for $6 \mathrm{~h}$, followed by evaporation of the solvent under reduced pressure. The residue was then dissolved in ethyl acetate and washed with $5 \%$ critic acid $(100 \mathrm{~mL} \times 2), \mathrm{NaHCO}_{3}(100 \mathrm{~mL} \times 2)$ and brine $(100 \mathrm{~mL} \times 2)$. The organic solvent was dried over anhydrous sodium sulfate, filtered, and evaporated under reduced pressure to obtain the crude product which was purified using column chromatography $(50 \%$ EtOAc/hexane $)$ to obtain compound 32 (145 mg, 68\%). The compound 32 (50 mg) was treated with $\mathrm{HCl}$ in dioxane solution and stirred for $2 \mathrm{~h}$ to obtain compound 2 (28.5 mg, 82\%). ${ }^{1} \mathrm{H}$ NMR (500 MHz, MeOD) $\delta 5.30(\mathrm{ddd}, J=8.0,6.5,2.8 \mathrm{~Hz}, 2 \mathrm{H}), 4.57(\mathrm{t}, J=5.7 \mathrm{~Hz}, 2 \mathrm{H}), 4.47$ (dd, $J=12.0,2.7 \mathrm{~Hz}, 2 \mathrm{H}$ ), 4.37 (dddd, $J=19.6,14.4,9.3,5.0 \mathrm{~Hz}$, $8 \mathrm{H}), 4.24$ (dd, $J=9.0,5.1 \mathrm{~Hz}, 2 \mathrm{H}), 4.17(\mathrm{dd}, J=12.0,6.7 \mathrm{~Hz}, 2 \mathrm{H})$, $3.96(\mathrm{dd}, J=11.0,5.4 \mathrm{~Hz}, 2 \mathrm{H}), 3.84(\mathrm{dd}, J=11.0,6.0 \mathrm{~Hz}, 2 \mathrm{H})$, $3.75-3.73(\mathrm{~m}, 1 \mathrm{H}), 3.69-3.65(\mathrm{~m}, 2 \mathrm{H}), 3.60-3.57$ (m, 1H), 3.28 (d, $J=5.1 \mathrm{~Hz}, 2 \mathrm{H}), 2.99(\mathrm{dt}, J=13.8,5.8 \mathrm{~Hz}, 18 \mathrm{H}), 2.89$ (dd, $J=14.6$, $9.0 \mathrm{~Hz}, 2 \mathrm{H}), 2.82(\mathrm{dd}, J=14.3,8.3 \mathrm{~Hz}, 2 \mathrm{H}), 2.35$ (dt, $J=13.3$, $7.4 \mathrm{~Hz}, 8 \mathrm{H}), 1.98-1.84$ (m, 9H), 1.83-1.66 (m, 24H), 1.66-1.44 $(\mathrm{m}, 25 \mathrm{H}), 1.39-1.15(\mathrm{~m}, 91 \mathrm{H}), 0.90(\mathrm{t}, J=7.0 \mathrm{~Hz}, 12 \mathrm{H}) .{ }^{13} \mathrm{C} \mathrm{NMR}$ (126 MHz, MeOD) $\delta$ 175.02, 174.98, 174.91, 174.21, 174.12, 174.06, 172.33, 168.94, 73.57, 72.45, 71.33, 65.23, 63.19, 62.17, $56.77,55.07,54.68,54.52,53.41,53.30,40.60,40.58,40.52$, $40.47,35.23,34.99,34.00,33.11,33.00,32.29,32.17,31.78$, $30.85,30.81,30.75,30.72,30.55,30.52,30.27,30.26,27.99$, 27.90, 27.85, 26.14, 26.07, 23.89, 23.86, 23.76, 23.64, 14.47. MS (ESI) calculated for $[\mathrm{M}+\mathrm{H}]^{+} \mathrm{C}_{65} \mathrm{H}_{127} \mathrm{~N}_{10} \mathrm{O}_{12} \mathrm{~S}^{+} \mathrm{m} / z$ 1271.93, found 1271.92.

\section{Conflicts of interest}

There are no conflicts to declare.

\section{Acknowledgements}

DBS is thankful to UGC New Delhi for start-up research grant and DBT New Delhi for the award of Ramalingaswami Fellowship. The support from UGC-CAS, DST-PURSE-II, DST-SAIF and Panjab University Development fund is gratefully acknowledged. AK is thankful to UGC, New Delhi for the award of Junior Research Fellowship. MTP is thankful to DST for the award of Women Scientist Scheme-A (WOS-A).

\section{References}

1 T. H. Mogensen, Clin. Microbiol. Rev., 2009, 22, 240.

2 T. Kawasaki and T. Kawai, Front. Immunol., 2014, 5, 1.

3 D. Werling and T. W. Jungi, Vet. Immunol. Immunopathol., 2003, 91, 1.

4 A. G. Dalgleish, Hum. Vaccines Immunother., 2014, 10, 3369. 5 T. Kawai and S. Akira, Nat. Immunol., 2010, 11, 373.

6 A. O. Aliprantis, R.-B. Yang, M. R. Mark, S. Suggett, B. Devaux, J. D. Redolf, G. R. Klimpel, P. Godowski and A. Zychlinsky, Science, 1999, 285, 736.

7 (a) M. S. Jin, S. E. Kim, J. Y. Heo, M. E. Lee, H. M. Kim, S. G. Paik, H. Lee and J. O. Lee, Cell, 2007, 130, 1071; (b) J. Y. Kang, X. Nan, M. S. Jin, S. J. Youn, Y. H. Ryu, S. Mah,
S. H. Han, H. Lee, S. G. Paik and J. O. Lee, Immunity, 2009, 31, 873.

8 M. Murata, Cancer Sci., 2008, 99, 1435.

9 N. Isambert, P. Fumoleau, C. Paul, C. Ferrand, S. Zanetta, J. Bauer, K. Ragot, G. Lizard, J. Jeanin and M. Bardou, BMC Cancer, 2013, 13, 172.

10 M. A. Moreno-Eutimio, A. Tenorio-Calvo, R. PastelinPalacios, C. Perez-Shibayama, C. Gil-Cruz, R. LopezSantiago, I. Baeza, M. Fernandez-Mora, L. Bonifaz, A. Isibasi, E. Calva and C. Lopez-Macias, Immunology, 2013, 139, 459.

11 A. Halliday, J. D. Turner, A. Guimarães, P. A. Bates and

M. J. Taylor, Parasites Vectors, 2016, 9, 96.

12 T. J. Powell, WO Pat., 2013148426A1, 2013.

13 A. Maruyama, H. Shime, Y. Takeda, M. Azuma, M. Matsumoto and T. Seya, Biochem. Biophys. Res. Commun., 2015, 457, 445.

14 M. C. Nawijn, A. C. Motta, R. Gras, S. Shirinbak, H. Maazi and A. J. M. Oosterhout, PLoS One, 2013, 8, e55307.

15 J. R. Slingluff, L. Craig and I. S. Mauldin, WO Pat., 201507003A1, 2015.

16 U. Buwitt-Beckmann, H. Heine, K. H. Wiesmuller, G. Jung, R. Brock and A. J. Ulmer, FEBS J., 2005, 272, 6354.

17 W. Zeng, S. Ghosh, Y. F. Lau, L. E. Brown and D. C. Jackson, J. Immunol., 2002, 169, 4905.

18 (a) J. W. Metzger, A. G. Beck-Sickinger, M. Loleit, M. Eckert, W. G. Bessler and G. J. Jung, Pept. Sci., 1995, 3, 184; (b) P. F. Muhlradt, M. Kiess, H. Meyer, R. Sussmuth and G. Jung, J. Exp. Med., 1997, 185, 1951; (c) P. F. Muhlradt, M. Kiess, H. Meyer, R. Sussmuth and G. Jung, Infect. Immun., 1998, 66, 4804.

19 D. B. Salunke, S. W. Connelly, N. M. Shukla, A. R. Hermanson, L. M. Fox and S. A. David, J. Med. Chem., 2013, 56, 5885.

20 D. B. Salunke, X. Guo and S. A. David, US Pat., 20150337009, 2015.

$21 \mathrm{~W} . \mathrm{Wu}, \quad$ R. Li, S. S. Malladi, H. J. Warshakoon, M. R. Kimbrell, M. W. Amolins, R. Ukani, A. Datta and S. A. David, J. Med. Chem., 2010, 53, 3198.

22 M. R. Kimbrell, H. Warshakoon, J. R. Cromer, S. Malladi, J. D. Hood, R. Balakrishna, T. A. Scholdberg and S. A. David, Immunol. Lett., 2008, 118, 132.

23 J. D. Hood, H. J. Warshakoon, M. R. Kimbrell, N. M. Shukla, S. S. Malladi, X. Wang and S. A. David, Hum. Vaccines, 2010, 6, 322 .

24 M. Azuma, R. Sawahata, Y. Akao, E. Takashi, S. Yamazaki, M. Matsumoto, M. Hashimoto, K. Fukase, Y. Fujimoto and S. Teya, PLoS One, 2010, 5, e12550.

25 J. C. Farges, F. Carrouela, J.-F. Keller, C. Baudouin, P. Msika, F. Bleicher and M.-J. Staquet, Immunobiology, 2011, 216, 513.

26 A. C. D. Salyer, G. Caruso, K. K. Khetani, L. M. Fox, S. S. Malladi and S. A. David, PLoS One, 2016, 11, e0149848. 27 L. W. Hamley, S. Kirkham, A. Dehsorkhi, V. Castelletto, M. Reza and J. Ruokolainen, Chem. Commun., 2014, 50, 15948.

$28 \mathrm{http}: / /$ www.invivogen.com/pam2csk4. 
29 N. Martin and E. J. Thomas, Org. Biomol. Chem., 2012, 10, 7952.

30 P. J. Garegg, T. Regberg, J. Stawinski and R. Strornberg, J. Chem. Soc., Perkin Trans. 2, 1987, 11, 271.

31 D. C. Batesky, M. J. Goldfogel and D. J. Weix, J. Org. Chem., 2017, 82, 9931.

32 L. Sambri, G. Bartoli, G. Bencivenni and R. Dalpozzo, Curr. Org. Synth., 2012, 9, 137.

33 P. Plastina, A. Fazio, M. Attya, G. Sindona and B. Gabriele, Nat. Prod. Res., 2012, 26, 1799.

34 D. B. Salunke, N. M. Sukhla, Y. Euna, B. M. Crall, R. Balakrishna, S. S. Malladi and S. A. David, J. Med. Chem., 2012, 55, 3353.

35 (a) Y. Hao, M. Zhang, J. He and P. Ni, Langmuir, 2012, 28, 6448; (b) S. H. Lee and H. Kohn, Heterocycles, 2003, 60, 47; (c) R. D. Besten, S. Hardeer and L. J. Brandsma, Organomet. Chem., 1990, 385, 153.
36 G. Agnihotri, B. M. Crall, T. C. Lewis, T. P. Day, R. Balakrishna, H. J. Warshakoon, S. S. Malladi and S. A. David, J. Med. Chem., 2011, 54, 8148.

37 S. A. David and N. M. Shukla, US Pat., 201202944885, 2012. 38 (a) A. Pratesi, M. Ginanneschi, F. Melani, M. Chinol, A. Carollo, G. Paganelli, M. Lumini, M. Bartoli, M. Frediani, L. Rosi, G. Petrucci, L. Messori and A. M. Papini, Org. Biomol. Chem., 2015, 13, 3988; (b) S. Banerjee, W. J. Wiggins, J. L. Geoghegan, C. T. Anthony, E. A. Woltering and D. S. Masterson, Org. Biomol. Chem., 2013, 11, 6307; (c) C. Kim, T. Young, Y. Cao, J. Ma, M. Kim, S. Pinkerton and P. G. Schultz, WO Pat., 2015057852, 2015.

39 J. T. Herpt, M. C. A. Stuart, W. R. Browne and B. L. Feringa, Chem. - Eur. J., 2014, 20, 3077.

40 M. L. Di Gioia, P. Costanzo, A. De Nino, L. Maiuolo, M. Nardi, F. Olivitod and A. Procopiod, RSC Adv., 2017, 7, 36482 . 